\title{
VIABILITY AND PLASMA MEMBRANE INTEGRITY OF THE SPOTTED BUFFALO EPIDIDYMAL SPERMATOZOA AFTER THAWING WITH THE ADDITION OF DEXTROSE INTO THE EXTENDER
}

\author{
YULNAWATI ${ }^{1}$, H. MAHESHWARI ${ }^{2}$, HERDIS ${ }^{3}$, M. RIZAL $^{4}$ \\ ${ }^{1^{*}}$ RC. Biotechnology, LIPI, Jl. Raya Bogor km. 46, Cibinong, 16911, \\ ${ }^{2}$ Dept of Anatomy, Physiology and Pharmacology, Faculty of Veterinary Medicine IPB, \\ Jl. Agatis IPB Campus, Darmaga, Bogor, 16680 \\ ${ }^{3}$ BPPT, Jl. MH. Thamrin Kav. 8, Jakarta \\ ${ }^{4}$ Dept. of Animal Husbandary, Faculty of Agriculture, Pattimura University, \\ Jl. Ir. M. Putuhena, Kampus Pokka, Ambon
}

\begin{abstract}
The objective of this study was to obtain the viability and plasma membrane integrity of the spotted buffalo epididymal sperm after addition of dextrose into Andromed ${ }^{\circledR}$ extender. Spermatozoa that have been collected from cauda epididymis were diluted with Andromed ${ }^{\circledR}$ extender as control $(\mathrm{K})$ and Andromed ${ }^{\circledR}+0.2 \%$ dextrose $(\mathrm{P} 1)$ and Andromed $^{\circledR}+0.4 \%$ dextrose (P2) as treatments. The results showed that the quality of epididymal spermatozoa decreased during cryopreservation process. The percentage of motility after thawing in P1 (46\%) and P2 (46.67\%) were significantly higher $(\mathrm{P}<0.05)$ compared to $\mathrm{K}(41 \%)$ as well as the percentage of live sperm in $\mathrm{P} 1(58.8 \%)$ and P2 (60\%) compared to K (52.2\%). The percentage of membrane integrity in P1, P2 and $\mathrm{K}$ were $67.4 ; 66.8$ and $68 \%$, respectively. In conclusion, the addition of 0.2 and $0.4 \%$ of dextrose into Andromed ${ }^{\otimes}$ acted as an extra cellular cryoprotectant and could maintain the viability and membrane integrity of the spotted buffalo epididymal spermatozoa after thawing.
\end{abstract}

Key words: epididymal sperm, cryopreservation, dextrose, spotted buffalo

\section{INTRODUCTION}

Indonesia is worldwide known to have high biodiversity that need to be considered for the conservation of the flora and fauna specific to this country. Spotted buffalo is one of the Indonesian biodiversity that need a particular attention as its population tends to decrease every year. This animal is thought to bring fortune and is usually used for the veneration in traditional ceremony in Tana Toraja, South Sulawesi. According to the local people believe, spotted buffalo can only survive in its natural habitat, which is in Tana Toraja. The farmer put a special treatment for the spotted buffalo; particularly the male is maintained separated from the female 
to prevent it from reproduction activities. This condition is, therefore, thought to make the conservation effort of this animal become more difficult.

One of the alternative attempts to prevent this animal from extinction is to utilize the gonad, which are the testis and the epididymis of the male that is sacrificed in the traditional ceremony. The epididymis can be used as a source of potential spermatozoa that can conserve the genetic material. The fertility of the spermatozoa taken from the cauda epididymis is more or less the same as the spermatozoa from the ejaculate (Hafez and Hafez 2000). Collection of the epididymal spermatozoa has been done in various species such as primate (Feradis et al. 2001), sheep (Rizal 2006), cattle (Graham 1994), cat (Tsutsui et al. 2003, Yulnawati and Setiadi 2005), pig (Kikuchi et al. 1998), rhinocerous (Lubbe 1999), equine (Squires et al. 2000; Papa et. al. 2008), deer (Soler et al. 2003), dog (Setiadi et al. 2007, Hori et al. 2004) and African buffalo (Herold et al. 2004, Herold et al. 2006). Spermatozoa collected from cauda epididymis is then stored in the form of liquid and/or frozen sperm. Furthermore, epididymal sperm could be used for assisted reproductive technology such as artificial insemination (AI), in vitro embryo production (IVEP) or intra cytoplasmic sperm injection (ICSI).

In order to maintain the quality of the spermatozoa during storage and after thawing for further process, the extender with a certain composition is needed. During the freezing process, the important material in the extender is the cryoprotectant that can protect sperm from coldshock. Cryoprotectant can directly prevent the formation of ice crystal in the cell, as well as working extracellularly as a membrane protector. Both the intracellular and extracellular cryoprotectants can be added at the same time in a certain ratio into the extender. Sugar is used in the research as one of the extracellular cryoprotectant that should be added to the glycerol-as intracellular cryoprotectant-contained Andromed ${ }^{\circledR}$ extender. It is hoped that the addition of dextrose sugar can maintain the viability dan integrity of plasma membrane of the spotted buffalo's epididymal spermatozoa after thawing.

\section{MATERIALS AND METHODS}

Cauda epididymis of the spotted buffalo was collected during the Rambu Solo' funeral ceremony in the Pangli village, Sesean, North Toraja. The cauda epididymis was flushed and stored in $0.9 \%$ of $\mathrm{NaCl}$ before the collection of spermatozoa. Epididymal spermatozoa was collected using combination technique, slicing/ flushing and pressing all parts of the cauda's tissues (Rizal et al. 2004) using Andromed ${ }^{\circledR}$ solution as an extender. Evaluation of the quality of fresh spermatozoa observed was percentage of progresive motility, percentage of live spermatozoa, concentration, percentage of abnormality and percentage of plasma membrane integrity (MPU). Collected spermatozoa was centrifuged at $500 \mathrm{G}$ for $20 \mathrm{~min}$. at room temperature. The supernatant was discharged and the pellet that contained spermatozoa was re-diluted with Andromed ${ }^{\circledR}$ (Minitub, Germany) extender. The volume of the extender used is based on the concentration previously calculated.

Basic extender used in this research was Andromed ${ }^{\circledR}$. Andromed ${ }^{\circledR}$ is a commercial extender that contains glycerol as an intracellular cryoprotectant. Andromed ${ }^{\circledR}$ without 
any addition of substance was grouped as control, whereas the addition of 0.2 and $0.4 \%$ w/v of dextrose (Merck, Germany) into Andromed ${ }^{\circledR}$ were grouped as treatments.

The diluted epididymal spermatozoa were placed in $0.25 \mathrm{ml}$ of mini straw with 60 million of motile spermatozoa per straw and equilibrated in the refrigerator at $5^{\circ} \mathrm{C}$ for 3 hours. Freezing of the epididymal spermatozoa was started by arranging the straw $10 \mathrm{~cm}$ above the surface of the liquid nitrogen with the temperature of $-130^{\circ} \mathrm{C}$ for $15 \mathrm{~min}$. Afterwards, the straw was plugged into the liquid nitrogen with the temperature of $-196^{\circ} \mathrm{C}$ and stored in the container. Later, each frozen epididymal spermatozoa sample was thawed for quality evaluation. Thawing process was carried out by placing the straw into the water bath at $37^{\circ} \mathrm{C}$ for 30 seconds.

The percentage of sperm motility, live sperm, and plasma membrane integrity of post diluted, equilibrated and thawed epididymal spermatozoa were recorded. The percentage of progresive motility (move forward) of the sperm was counted subjectively at eight different visual fields, using light microscope with the magnitude of 400x. The percentage of live sperm was counted using eosin staining. Live spermatozoa were characterized by white colour of the head, whereas the dead sperm had red head (Toelihere 1993). Plasma membrane integrity (MPU) was characterized by circular tail or inflated, whereas the broken one was characterized by by straight tail when the sperm was exposed to the hypoosmotic solution and incubated at $37^{\circ} \mathrm{C}$ for $60 \mathrm{~min}$ (Revell and Mrode 1994). For each parameter observed, a sum of minimum 200 sperma was evaluated using light microscope with the magnitude of 400x.

Data obtained were analyzed using random Analysis of Variance (ANOVA) with three treatments and five replications. Difference between treatments was tested using Duncan multiple range test (Steel and Torrie 1993).

\section{RESULTS AND DISCUSSIONS}

The quality of fresh epididymal spermatozoa of the spotted buffalo obtained from this research is shown in Table 1. The concentration of spermatozoa collected from the cauda epididymis using flushing technique and pressure, was $10445 \times 10^{6}$ spermatozoa $/ \mathrm{ml}$. Theoretically, this was reliable because cauda epididymis functions as a spermatozoa storage before ejaculation and in the cauda and the spermatozoa has not have seminal plasma addition (Garner and Hafez 2000). The sperm concentration in bull cauda epididymal was 3593 - 4406,7 x $10^{6} \mathrm{sperm} / \mathrm{ml}$ (Suhendra 2002) and $6,26 \times 10^{9} \mathrm{sperm} / \mathrm{ml}$ in buffalo cauda epididymal tissue (Toelihere 1993).

Table 1. The avarage quality of fresh spotted buffalo epididymal spermatozoa

\begin{tabular}{lc}
\hline \multicolumn{1}{c}{ Parameters } & Mean \pm st.dev \\
\hline Concentration $\left(\mathrm{x} 10^{6}\right.$ sperma/ml) & $10445 \pm 43.62$ \\
Volume (ml) & 0.45 \\
Progressive motility (\%) & $65.0 \pm 0.00$ \\
Live (\%) & $79.3 \pm 1.30$ \\
Abnormality (\%) & $15.0 \pm 2.24$ \\
Plasma Membrane Integrity (\%) & $80.8 \pm 0.43$ \\
\hline
\end{tabular}


The percentage of the epididymal spermatozoa motility obtained from the research was $65 \%$ and this value is still in the range of the requirements for using it in the artificial insemination (AI) application. The percentage of the abnormality of this epididymal spermatozoa was also high (15\%), however this value is still in the normal range and reliable to be used for fertilization process, since the normal fertile semen contains not more than $20 \%$ abnormal spermatozoa (Ax et al. 2000). The percentage of abnormal morphology of $8-10 \%$ did not give any significant effect to the fertility, however, if the abnormality form one ejaculate which is more than $25 \%$, the decrease of the fertility could not be anticipated (Bearden and Fuquay 1997).

Generally, after undergoing three steps of freezing process, the research indicated that the percentage of the motility, viability and plasma membrane integrity of the treatment groups were better compared to the control group. The percentage of motility after thawing in the control group, dextrose 0.2 and $0.4 \%$, were 41,46 and $46.67 \%$, respectively. There was a significant difference $(\mathrm{P}<0.05)$ between treatment groups which had dextrose addition and the control group. On the other hand, there was no significant difference $(P>0.05)$ between treatment groups and the control group of the percentage of plasma membrane integrity (Table 2). It could be concluded that the value of post thawing epididymal sperm still met the requirements for AI, IVF or ICSI application.

Table 2. The mean ( \pm stdev) percentage of motility and viability of epididymal spermatozoa of spotted buffalo at different stages of freezing processes

\begin{tabular}{ccccc}
\hline Frozen Stage & Parameters & Control & Dextrose 0,2\% & Dextrose 0,4\% \\
\hline Dilution & $\% \mathrm{M}$ & $65,00 \pm 0,00^{\mathrm{a}}$ & $65,00 \pm 0,00^{\mathrm{a}}$ & $65,00 \pm 0,00^{\mathrm{a}}$ \\
& $\% \mathrm{Live}$ & $76,00 \pm 2,83^{\mathrm{a}}$ & $82,00 \pm 1,41^{\mathrm{b}}$ & $82,67 \pm 1,25^{\mathrm{b}}$ \\
& $\% \mathrm{MPU}$ & $78,67 \pm 0,47^{\mathrm{a}}$ & $77,33 \pm 2,87^{\mathrm{a}}$ & $80,00 \pm 0,82^{\mathrm{a}}$ \\
\multirow{3}{*}{ Equilibration } & $\% \mathrm{M}$ & $50,00 \pm 0,00^{\mathrm{a}}$ & $56,67 \pm 4,71^{\mathrm{a}}$ & $56,67 \pm 4,71^{\mathrm{a}}$ \\
& $\% \mathrm{Live}$ & $70,33 \pm 0,47^{\mathrm{a}}$ & $73,00 \pm 1,89^{\mathrm{a}}$ & $72,67 \pm 1,25^{\mathrm{a}}$ \\
& $\% \mathrm{MPU}$ & $72,00 \pm 0,82^{\mathrm{a}}$ & $71,33 \pm 0,94^{\mathrm{a}}$ & $73,00 \pm 0,82^{\mathrm{a}}$ \\
& $\% \mathrm{M}$ & $41,00 \pm 2,00^{\mathrm{a}}$ & $46,00 \pm 2,00^{\mathrm{b}}$ & $46,67 \pm 2,36^{\mathrm{b}}$ \\
& $\% \mathrm{Live}$ & $52,20 \pm 2,48^{\mathrm{a}}$ & $58,80 \pm 1,83^{\mathrm{b}}$ & $60,00 \pm 0,82^{\mathrm{b}}$ \\
& $\% \mathrm{MPU}$ & $68,00 \pm 1,10^{\mathrm{a}}$ & $67,40 \pm 1,36^{\mathrm{a}}$ & $66,80 \pm 1,47^{\mathrm{a}}$ \\
\hline
\end{tabular}

Note:

M: motility, MPU: plasma membrane integrity, ${ }^{a, b}$ Different superscript in the different column showed significantly different $(\mathrm{P}<0,05)$.

Dextrose is produced by the conversion enzyme found in cornstarch and undergoes demineralization ion exchange process. Dextrose is the form of D-glucose that can be metabolized by the cell through biochemical process called glycolysis to be an energy source. In general, the addition of the sugar into the spermatozoa extender can affect the motility, viability and plasma membrane integrity of the spermatozoa. The addition of sugar into the extender can diminish the damage of the spermatozoa acrosome (Yildiz et al. 2000). Sugar is known as an extracellular cryoprotectant. The mechanism of how dextrose works in this research is assumed as a protector for the plasma membrane rather than to prevent the formation of the ice crystal in the cell. 
Whereas, glycerol already contained in the Andromed ${ }^{\circledR}$, play a role as intracellular cryoprotectant, to prevent the formation of ice crystal during freezing process.

There are no reports of experiments on the epididymal sperm of spotted buffalo freezing and thawing process. Therefore, none of the publications reported on the use of sugar that was added into the basic extenders in spotted buffalo sperm cryopreservation process. For the references, the use of sugar as cryoprotectant in different animal species were reported, such as sheep (Aisen et al. 2002; Molinia et al. 1994), dog (Yildiz et al. 2000; Rigau et al. 2001), pig (de los Reyes 2000) and bull (Woelders et al. 1997). Generally, sugars play a role as the capacity agent of cryoprotectant and works as the spermatozoa plasma membrane protector during freezing process. It was also known that the sugars have dehydration activity and be able to interact with the cell membrane (Aisen et al. 2000).

\section{CONCLUSIONS}

In conclusion, recovered spermatozoa from cauda epididymis of spotted buffalos that undergo freezing processes using Andromed with the addition of 0.2 or $0.4 \%$ dextrose are suitable for AI.

\section{ACKNOWLEDGMENTS}

This research was finacially supported by DIPA BIOTROP 2008, No: 047.1/ PSRP-SP/III/2008. Special thank goes to the Head of Animal Division in North Toraja, Dr. Yulius and Mr. Slamet Sumitro for supplying the cauda epididymis samples and using the laboratory facilities.

\section{REFERENCES}

Aisen E.G., Alvarez H.L., Venturino A. and J.J. Garde. 2000. Effect of trehalose and EDTA oncryoprotective action of ram semen diluents. Theriogenology, 53(5): 1053-1061.

Aisen E.G., Medina V.H. and A. Venturino. 2002. Cryopreservation and post-thawed fertility of ram frozen semen in different trehalose concentrations. Theriogenology, 57:1801-1808.

Ax R.L., Dally M., Didion B.A., Lenz R.W., Love C.C., Varner D.D., Hafez B. and M.E. Bellin. 2000. Semen Evaluation. In: Hafez B and Hafez ESE. Reproduction in Farm Animals. $7^{\text {th }}$ Ed. Philadelphia: Lea and Febiger. p. 365-375

Axner E., Sormholst B. and C. Linde-Forsberg. 1998. Morphology of spermatozoa in the cauda epididymis before and after electroejaculation and comparison with ejaculated spermatozoa in the domestic cat. Theriogenology, 50 (6): 973-979. 
Bearden H.J. and J.W. Fuquay. 1997. Applied Animal Reproduction. $4^{\text {th }}$ Ed. New Jersey: Prentice Hall, Upper Saddle, p. 133-177. de los Reyes M., Saenz L., Lapiere L., Crosby J., and C. Barros. 2000. In vitro evaluation of boar spermatozoa frozen with permeable and non permeable cryoprotectant. Proceeding $14^{\text {th }}$ International Congress on Animal Reproduction. Stockholm 2-6 July 2000. p. 161. Abstract Vol. 2.

Feradis A.H., Pawitri D., Suatha I.K., Amin M.R., Yusuf T.L., Sajuthi D., Budiarsa I.N. and E.S.Hayes. 2001. Cryopreservation of epididymal spermatozoa collected by needle biopsy from cynomolgus monkeys (Macaca fascicularis). J. Med. Primatol., 30: 100-106.

Garner D.L. and E.S.E. Hafez. 2000. Spermatozoa and Seminal Plasma. In: Hafez B and Hafez ESE. Reproduction in Farm Animals. $7^{\text {th }}$ Ed. Philadelphia: Lea and Febiger, p. 96-109

Graham J.K. 1994. Effect of seminal plasma on the motility of epididymal and ejaculated spermatozoa of the ram and bull during cryoprservation process. Theriogenology, 46: 1151-1162.

Hafez E.S.E. and B. Hafez. 2000. Reproduction in farm animals. $7^{\text {th }}$ Ed. Baltimore: Lippincott Williams \& Wilkins.

Herold F.C., Aurich J.E. and D. Gerber. 2004. Epididymal sperm from the African buffalo (Syncerus caffer) can be frozen successfully with Andromed ${ }^{\circledR}$ and Triladyl ${ }^{\mathrm{TM}}$ but the addition of bovine seminal plasma is detrimental. Theriogenology, 61: 715-724.

Herold F.C., de Haas K., Colenbrander B. and D. Gerber. 2006. Comparison of equilibration times when freezing epididymal sperm from African buffalo (Syncerus caffer) using Triladyl ${ }^{\mathrm{TM}}$ or Andromed $^{\circledR}$. Theriogenology, 66: 1123-1130.

Hori T., Ichikawa M., Kawakami E. And T. Tsutsui. 2004. Artificial insemination with frozen epididymal sperm beagle dogs. J. Vet. Med. Sci. ; 66(1): 37-41.

Kikuchi K., Nagai T., Kashiwazaki N., Ikeda H., Noguchi J., Shimada A., Soloy E. and H. Kaneko. 1998. Cryopreservation and ensuing in vitro fertilization ability of boar spermatozoa from epididymides stored at $4^{\circ} \mathrm{C}$. Theriogenology, 50:615-623.

Lubbe K., Smith R.L., Bartels P. And R.A. Godke. 1999. Freezing epididymal sperm from white rhinoceros (Ceratotherium simum) treated with different diluents. Theriogenology, 51:288. Abstract.

Molinia F.C., Evans G., Quintana Casares P.I. and W.M.C. Maxwell. 1994. Effect of monosaccharidaes and dissacharides in Tris-based diluents on motility, acrosome integrity and fertility of pellet frozen ram spermatozoa. Anim. Reprod. Sci., 36(1-2): 113-122.

Papa F. O., Melo C. M., Fioratti E. G., Dell'Aqua Jr. J. A., Zahn F. S. and M. A. Alvarenga. 2008. Freezing of stallion epididymal sperm. Anim. Reprod Sci., 107(3-4): 293-301.

Revell S.G. and R.A. Mrode. 1994. An osmotic resistance test for bovine semen. Anim. Reprod. Sci. , 36:77-86.

Rigau T., Farre M., Ballester J., Mogas T., Pena A. and J.E. Rodriquez-gil. 2001. Effect of glucose and fructose on motility patterns of dog spermatozoa from fresh ejaculate. Theriogenology, 56(5): 801-815.

Rizal M. 2006. The fertility of frozen-thawed ejaculate vs epididiymal Garut ram sperm. Veterinary Sains J., 24: 49-57. 
Epididymal spermatozoa of the spotted buffalo - Yulnawati et al.

Rizal M., Herdis and A. Boediono . 2004. Viability of ram sperm epididymal after storage at $5^{\circ} \mathrm{C}$. J. Anim. Prod. , 6(1): 30-36.

Setiadi M.A., Yulnawati and A. Suprayogi. 2007. The quality of dog epididymal sperm during storage at $4^{\circ} \mathrm{C}$. JITV., 12 (2): 134-138.

Soler A.J., Perez-Gusman M.D. and J.J. Garde. 2003. Storage of red deer epididymides for four days at $5^{\circ} \mathrm{C}$ : effects on sperm motility, viability, and morphology integrity. J. Exp. Zool., 295A: 188-199.

Steel R.G.D. and J.H. Torrie. 1993. Principles and Procedures of Statistic. London: Mc Graw-Hill Book Co. Inc. Pub. Ltd.

Squires E.L., Gomez-Cuetara C. and J.K. Graham. 2000. Effect of seminal plasma on cryopreserving epididymal and ejaculated stallion spermatozoa. Proceedings $14^{\text {th }}$ International Congress on Animal Reproduction. Stockholm, 2-6 July 2000; 2, p.166.

Suhendra. 2002. The study about some parameters of bull sperm quality in different part of epididymis. Bachelor Thesis. Bogor: Faculty of Veterinary Medicine, Bogor Agricultural University.

Toelihere M.R. 1993. Artificial Insemination in Animals. Bandung: Angkasa.

Tsutsui T., Wada M., Anzai M. and T. Hori. 2003. Artificial insemination with frozen epididymal sperm in cats. J. Vet. Med. Sci. , 65 (3): 397-399.

Woelders H., Matthij A. and B. Engel. 1997. Effects of trehalose and sucrose, osmolality of the freezing medium, and cooling rate on viability and intactness of bull sperm after freezing and thawing. Cryobiology, 35:93-105.

Yildiz C., Kaya A., Aksoy M. and T. Tekeli. 2000. Influence of sugar supplementation of the extender on motility, viability and acrosomal integrity of dog spermatozoa during freezing. Theriogenology, 54(4): 579-585.

Yulnawati and M.A. Setiadi . 2005. Motility and membrane integrity of cat epididymal sperm during storage at $4^{\circ} \mathrm{C}$. Med. Vet J., 21(3): 100-104. 
Thank you for evaluating AnyBizSoft PDF Splitter.

A watermark is added at the end of each output PDF file.

To remove the watermark, you need to purchase the software from

http://www.anypdftools.com/buy/buy-pdf-splitter.html 